\title{
Toward the Future EU Growth: Capital Markets Union and Structural Reforms
}

\author{
Antonin Rusek ${ }^{1}$ \\ ${ }^{1}$ Department of Economics, Susquehanna University, Selinsgrove, USA \\ Correspondence: Antonin Rusek, Department of Economics, Susquehanna University, Selinsgrove, PA 17870, USA.
}

Received: November 9, 2016

Accepted: November 30, $2016 \quad$ Online Published: December 8, 2016

doi:10.5430/ijfr.v8n1p1

URL: http://dx.doi.org/10.5430/ijfr.v8n1p1

\begin{abstract}
The progress of globalization confronts the EU with the new challenges. To answer these, the restoration of growth is the imperative. The competitiveness especially on the Mediterranean littoral and hopefully the real convergence must be restored. Renewal of the North to South capital flows is the sine qua non of this development. The key in this endeavor is the capital markets union, which will facilitate the increased activities of the venture capital - the main tool to create the new economy of innovation and creativity. But to be successful the capital markets union has to be complemented by reforms of labor markets, business creation environment and taxation. New approaches like special "economic innovation and growth" zones may be necessary. To fully implement the necessary structural reforms the cooperation of the private and public sectors on both the EU and national levels is necessary.
\end{abstract}

Keywords: challenges of globalization, capital flows, capital markets union, venture capital

\section{Introduction}

The result of the British EU referendum in June 2016 brought to the forefront the issue of the future of the European Union. The key here is to find some mechanism which would reconcile the organizational need for a structural stability with the flexibility required for effective responses to a changing social and economic reality, both externally and internally.

Each organization (and EU is undoubtedly one) needs a modicum of structural and behavioral stability. This includes social, political and economic institutions, legal system and, indeed, most of both external and internal environments. Such a stability makes the results of decisions of all agents predictable (albeit only in a statistical sense) - hence it provides for a dynamically functioning society in all its aspects.

Simultaneously, an organization must be flexible enough to cope with challenges stemming from changing both external and internal environments. For political-economic organizations (independent states and state-like entities) the most important internal challenges stem from economic-technological dynamics (which includes the impact of innovation processes) and demographics, which includes changing age cohorts, immigration dynamics and the impact of education in general. External challenges are then direct - i.e. the threat that the external agents or environment will, in a one form or another, extinguish the organization - or indirect, when changes in external environment make a functioning of an organization increasingly difficult.

The development of nation-states was an answer to "internal" challenges, an attempt to create the type of a social and political organization able to internalize the consequences of a rapidly changing economy and the population rise via rapid urbanization. Whereas successful as far as the "internal" challenges were concerned, the rise of the nation-state exacerbated the "external" challenges, which for many nation-states became destructive.

European answer to this situation was to pool the forces of nation-states. Forming a block of nation-states committed to economic and political cooperation aimed at eliminating large parts of external challenges stemming from conflicts between those states. Moreover, by forming a military alliance with the USA (NATO), the major existential threat to (west)European societies (Soviet Union) was contained. The rest of the world constituted no effective external challenges to (west) European economies in the post WWII period.

As far as the internal challenges are concerned, the basic idea was that (a gradual) creation of the European economic space will create the conditions for a sustained economic growth, will facilitate the ability of participating entities 
(nation states) to absorb a potentially disrupting impact of changing technologies and will create a resources for the "European model" of a social market economy welfare state.

Realities of the post WWII world made the last described policies rather extraordinarily successful. European countries participating in the "commonality" project - starting from the Common Market (operational from January $1^{\text {st }}, 1958$ ) and peaking in the project of the European Union (effective from November $1^{\text {st }}$, 1993) achieved the increases in the standard of living never experienced before outside the USA. The commitment to political democracy and the welfare state (known as the "European economic model") made the European political and economic community (EU from 1993) very attractive for its neighbors.

\section{Times of Change}

The collapse of the Soviet Russia empire (known as Soviet Union) and the liberation of the enslaved nations in the East-Central Europe represented a radical change for the emerging European community and its integration processes.

Externally, the existential threat to Europe from the East receded (temporarily, as it turned out). However, the slate of newly liberated Central and East European countries formed the region of potential political and economic instability on the European community's eastern boundaries. That was just exacerbated by the withdrawal of the bulk of US land and air forces from their European stations.

Greatest "internal" challenge was perceived to be the re-unification of Germany. Political leaders in Western Europe were afraid that the newly enlarged Germany (but still a third smaller than its historical territory) will abandon its commitment to the European community.

Answer to these newly perceived sources of both internal and external challenges was twofold. To cope with the new external challenges, EU offered the newly liberated countries of central and eastern Europe the path to membership, provided that these countries establish functioning political democracies and markets economies. This process was protracted, but it was successfully crowned by the full EU membership in 2004 and 2007 respectively (Bulgaria and Romania at the latter date). (It should be remarked here that the life saving external protection for all affected countries - was provided via the NATO membership in 1999).

As far as the "challenge" of the German unification is concerned, the European leaders (including the German ones) sought the answer in accelerating the role and power of "European" structures (economic, political and legal) over the nation-states. The idea here was to limit the space for individual countries independent action - and hence to preserve the stability of the European integrated space as a precondition for the future successful development. (The creation of the common currency Euro is the most visible manifestation of this approach.)

This approach was formalized and made operational gradually, starting with the epoch-making treaty of Maastricht (operational November $1^{\text {st }}, 1993$ ), which established the European Union (EU) and charted the path toward the common European currency Euro. Under the Treaty of Amsterdam (in force from May $1^{\text {st }}, 1999$ ), member states agreed to devolve certain powers from national governments to the European Parliament across diverse areas, including legislating on immigration, adopting civil and criminal laws, and enacting foreign and security policy (CFSP), as well as implementing institutional changes for expansion as new member nations join the EU. Treaty of Nice (in force from February $1^{\text {st }}$, 2003) handled the institutional aspects which needed adjustment due to the coming eastward expansion. Finally, the treaty of Lisbon (operational from December $1^{\text {st }}, 2009$ ) finalized the institutional and decision making structure of the then 28 members strong EU (the $29^{\text {th }}$ member - Croatia - joined July $1^{\text {st }}, 2013$ ).

For almost two decades this approach worked fairly well, even if there were some bumps on the road. Euro was successfully established in January 1999 for business transactions, with coins and banknotes issued from January 2002. The first and biggest round of the "eastern" expansion was completed in May 2004, when Latvia, Lithuania, Estonia, Poland, Czech Republic, Slovakia, Slovenia, Hungary, Malta and the Greek Cyprus became full fledged EU members. (This process continued in 2007 when Romania and Bulgaria became members and in 2013 when Croatia joined the EU.)

Indeed, there were some problems. When Germany and France violated the original Stability and Growth Pact (SGP - established in 1998 to ensure a budgetary discipline in the Euro area) in 2003 and 2004, the SGP was changed in the direction of more "flexibility" and accommodation to the large EU members. And the "European Constitution", designed to be the crown jewel of the European political social and economic integration, was rejected in 2005 by the popular referenda in France (May 2005) and Netherlands (June 2005). The project was consequently scrapped. The above mentioned Lisbon Treaty replaced (partially) the concept of the Europe-wide constitution with the intergovernmental treaty, covering basically the same areas. 
Overall, the first two decades (almost) of the EU established by the Maastricht Treaty and the first decade of the common currency Euro were considered a success. The celebratory mode was reflected in the official EU publications (EMU@10, 2008). The future was eagerly and optimistically expected. However....

\section{The Gathering Clouds}

The establishment of EU (via Maastricht and the subsequent treaties Amsterdam, Nice and Lisbon) addressed the challenges to European community stemming from the unification of Germany and the liberation of Eastern Europe. Simultaneously, it created new "internal" challenges.

The introduction of the common currency Euro and the centralization of some traditionally nation-state policy functions on the EU level created the new economic and political reality for some of those states, especially in the South (Mediterranean littoral).

The creation of the common economic space with the common currency implies the common nominal interest rates. Assuming that markets perceive future expected inflation rates and country risks as more or less equal across the common currency area, this translates to the common nominal interest rates

However, in reality the inflation differentials remained, inflation being higher in the Mediterranean countries compared to the countries North of Alps, albeit significantly lower compared to the pre-Euro era. (The reasons are complex and still not well understood. The structure of labor markets, sustained capital inflows increasing domestic demand and the complicated dynamics of a goods prices arbitrage are the major explanations.). Result was a protracted period of lower real interest rates in the Mediterranean countries (from now on referred to as "South"), leading to an increased demand in the interest rates sensitive areas especially in construction and consumption of durables. Given the relatively low domestic savings rate, this had to be financed by capital inflows. A sustained increase in domestic demand in South contributed to an economic growth (and hence the rising tax revenues), but simultaneously to wage and unit labor costs increases which both sustained a higher domestic inflation and led to the real exchange rates appreciation.

Having lost the ability to preserve the real value of their currencies via gradual nominal depreciation, the Mediterranean countries were gradually loosing competitiveness both inside the EU and externally (to the rest of the world). Capital inflows masked the magnitude of the problem, but, indeed, the loss of Southern competitiveness and resulting divergence in economic dynamics defines the major internal challenge for the EU in the second decade of the $21^{\text {st }}$ century.

The rise of the emerging markets constituted and will constitute in the future the major external challenge for the both EU as a whole and some member states. The nature of this challenge lies in its asymmetric impact on EU member states. The bulk of EM exports is in consumer goods area, intensifying the competitive challenges for the states on the Mediterranean littoral. On the other side, EMs still depend on the capital goods imports for their growth, which creates the opportunities for capital goods exporters - the EU countries north of Alps (subsequently referred to as "North"). This exacerbates divergence tendencies in the EU's economic dynamics. Common economic policies (especially monetary, but others as well) become difficult even to formulate, not to mention to execute.

Tendencies described above did not go unnoticed (Chen at al, 2012, Rusek, 2012). However, they were ignored by the EU policy makers, probably because their impact on the EU members economies during the most of the first decade of $21^{\text {st }}$ century remained rather limited.

\section{The Crisis and Response}

The onset of financial "crisis" changed things. North to South capital flows abruptly stopped, revealing fiscal, financial and competitiveness weaknesses of Mediterranean littoral economies. To stabilize the situation, these countries were forced to adopt the policies of fiscal and income restrain, commonly known as either "austerity" or "internal devaluation".

The outbreak of the crisis exposed both the policy and structural weaknesses in some member states and the lack of institutional mechanisms and policy tools on the EU level which would facilitate the effective community response.

Subsequently (and as the consequence of the revealed lack of preparedness), the new institutions on the EU level were established between 2011 and 2013, aimed at the creation of a mechanism which would facilitate stabilizing, both fiscally and financially, the most affected countries. The primary goal was (and is) to prevent the countries under a growing stress to be forced to abandon the common currency and perhaps even the EU itself. Simultaneously the institutional structure was established designed to coordinate (and supervise) the policies of individual Eurozone member states (with emphasis on fiscal sustainability). The goal is to prevent future crises. 
The most important among those steps is the adoption of the Treaty on Stability, Coordination and Governance in the Economic and Monetary Union (TSCG), commonly called Fiscal Stability Treaty. The TSCG became the integral part of the EU legal system (even if it is formally specified as "intergovernmental treaty", not the "EU law"). For details and precise formulations, see TSCG (2012).

Simultaneously, the EU commission adopted the so called "sixpack" - the set of five regulations and one directive (hence "sixpack") aimed at the strengthening of the fiscal discipline (including the budgetary and debt limits and the disciplining corrective measures) and preventing and correcting macroeconomic and competitiveness imbalances. (Details are available on the ECOFIN webpage.)

Both TSCG and "sixpack" are intended to run simultaneously in the future, reinforcing the one another and subsequently creating the budgetary stability and competitiveness environment conducive to the stabilization and growth in the common currency area.

The third "longterm" set of the new policies is the so called European Semester. It introduces the cycle of the economic policy coordination via the processes of consultation, evaluation and adjustments of national budgets. The goal is to ensure the more stability and a better synchronization of the national fiscal policies in the line with conditions and restrictions of TSCG (Eurozone Portal, 2014).

Finally, in May 2013, the new legislative measures (the so called 'two-pack') were enacted. Their goal is to improve the budgetary coordination via a common budgetary timeline for the euro area member states and the possibility for the European Commission to assess the national budgetary plans prior to their adoption. Secondly, the "two-pack" improves the economic and financial coordination in the euro area by facilitating the enhanced surveillance (by the European Commission) of a member state experiencing serious financial difficulties or a financial sector instability.

To provide resources for a conditional financial assistance to the Eurozone member countries in difficulties, the EU decided to establish a large permanent fund called the European Stability Mechanism (ESM). To overcome the legal ambiguity, the ESM was established as an amendment to the Lisbon treaty, currently the ruling EU document.

In this context the two aspects of the above mentioned measures (TSCG, "Sixpack", the European semester and "two-pack") should be stressed. The first is that the politically very important concept of EU (and Eurozone) as the community of the intergovernmental treaties is preserved. Even the dominant element (TSCG) is based on the idea that its rules, restrictions and regulations will become the organic parts of the individual nations legal systems preferably constitutions.

Secondly, no resource transfers beyond the previously existing agreements (preexisting EU budget, regional and convergence funds) are either involved or envisaged. Significantly, within the agreed upon fiscal limits and surveillance procedures, the structures of taxation and spending remain solely in national jurisdictions, reflecting the diversity in national preferences, history, culture and differing political constraints.

All measures described above constitute the framework designed to address the perceived shortcomings of the eurozone's architecture. The purpose is twofold. On the one side it is to provide for the medium to long term enforceable stability of public finances, preserving to a significant degree the autonomy and decision making structures of the participating states. On the other side, the ESM provides the institution designed to deal with unpredictable structural shocks to the member states finances.

The establishment of the "new Eurozone stability architecture", together with the ECB's OMT program were successful in what they intended to do - namely stabilizing both fiscally and financially countries most affected by the crisis and "calming" the financial markets. The underlying purpose - to save the Economic and Monetary Union and the common currency Euro was, for a time being, achieved. And the main purpose of the "banking union" (currently under construction) is to cement this achievement.

Whereas the policies referred to above restored the nominal stability for the Eurozone and therefore preserved the common currency, the same steps resulted in a widening gap between the Northern tier and the Mediterranean countries. This is the new internal challenge, only reinforced by the continuing external challenge of the rising emerging markets.

\section{The Way Forward}

In the next decade or so, the EU in general and the Eurozone in particular will face a complex set of challenges, both internally and externally. And, indeed, the demographic dynamics will exert influence over both the productivity and the fiscal positions. 
To confront successfully these challenges, the restoration of growth is the imperative for the EU and the Eurozone's future. However, not any growth will do. The emerging markets challenge requires a growth based on the innovation and creativity (i.e. the increases in productivity), especially in the South. This type of growth improves competitiveness and should arrest and hopefully reverse the divergence tendencies. Moreover, its fiscal implications would help to address the looming demographic challenges - especially the rising expenditures on pensions and healthcare across the EU.

In this context, the three issues emerge. The first and the most important one is the fact that the economic activities associated with the innovation and creativity are inherently riskier than the expansion of the existing business endeavors. That creates a funding problem. European financial sector, dominated by banks, is unsuitable to finance the new innovative but overall highly risky business ventures, especially if those are undertaken by newly created firms.

The second issue relates to labor markets. The uncertainty associated with innovative ventures will be reflected in the need for flexible labor contracts, especially if these ventures are carried by the newly established firms. Moreover, the act of an establishment of a new enterprise faces complicated procedures in many, especially southern countries. Liberalization of the entry into professions and business activities in general together with labor markets reforms are required to facilitate the desired economy of a growing productivity, i.e. the competitive and innovative economy.

Finally, the third issue is taxation. An increased uncertainty associated with the new enterprises constituting the new productive and innovative sector can be counteracted, at least partially, by designing a simplified (and perhaps even temporarily reduced) tax liability structure which would enhance the attractiveness of this sector for both the potential entrepreneurs and employees.

To address all three issues, actions on both the EU level and national levels are required. (Only the steps including the EU will be addressed here, but including the area where the EU and member states should act together in a coordinated manner.)

Venture capital firms are the key vehicle for the creation and financing of the new innovative companies which in turn are the essence of the dynamic, productivity enhancing growth. The actual funds for the venture capital come from existing financial establishments, technically termed the "limited investors". (In the US these compose of the pension funds, university endowments, insurance companies, various investment and hedge funds etc.) To be able to allocate a relatively small part of their funds to the high risk but high expected return venture capital, the "limited investors" need the continuous ability to diversify and hedge the rest of their portfolios - i.e. to continually optimize the overall portfolio's risk-return configuration. This in turn requires the financial markets which are broad (in terms of the number of instruments available to trade), deep (in terms of the large number of instruments available with different risk-return characteristics) and liquid. The large and sophisticated US financial markets provide the environment in which both venture capital firms and "limited investors" strive.

The EU economy as a whole (even without the UK) is greater than US, so theoretically it should be able to support the non-bank financial sector comparable to US. However, despite the advances of the last 15 years, European financial sector remains dominated by banks. Relatively small non-bank financial sector then does not provide a fertile environment for the venture capital.

Venture capital activity is the key for the creation of new firms which enhance productivity and competitiveness in the whole EU, but especially in the most negatively affected countries on the Mediterranean littoral. It would follow that the creation of a supportive environment for the venture capital activities should be one of the major goals for both the European commission, representatives of member states and the EU as a whole.

Indeed, the leadership of the EU recognizes the importance of the non-banking financial sector on a trans-european scale (Juncker, 2014, Hill, 2014). On the analytical side, the importance of the integrated pan-european non-banking financial sector - called the "capital markets union" (CMU) is discussed by Veron (2014). What is needed is the accelerated path of the CMU establishment, with the emphasis on its role in facilitating the activities of the venture capital in the EU in general and in its Mediterranean member countries in particular.

The creation of the CMU as vehicle to restore the free flow of capital within the EU in general and the Eurozone in particular is the key to the political and economic stabilization of the Eurozone and the EU. It should help to restore the North to South capital flows and by facilitating both the venture capital financing to help the South to promote the productivity growth and restore the competitiveness. (In contrast to the pre-recession situation where a significant amount of capital flows financed increased consumption.) And, indeed, the role of the European institutions is crucial in this undertaking. 
However, the CMU alone is not enough to restore the Southern growth and, hopefully, the real convergence. The substantive structural changes in the Mediterranean littoral economies are needed to make these countries attractive location for the venture capital.

Indeed, structural reforms are at the heart of changes associated with Treaty on Stability, Coordination and Governance in the Economic and Monetary Union (TSCG), the key element of the European response to the recent fiscal and financial turmoil. However, the experience of the last half a decade indicates the difficulties, opposition and widespread resentment encountered when structural changes are implemented across the individual national economies.

To facilitate the environment which will be inviting to the venture capital endeavors - and hence providing for the start of the growth based on the innovation and productivity - perhaps a different approach should be attempted.

Individual countries should designate "economic growth and innovation areas" defined either territorially or perhaps as branches of economic activities. Within those areas, the structural reforms should be accelerated, with the aim to create a hospitable environment for the new businesses, preferably financed by the venture capital.

The creation of such areas will necessarily be country specific. Hence their establishment must be the common projects of the EU institutions and the relevant country political and economic partners. Note that the goal is to facilitate the increase in the economic activity (and hence the employment) by establishing the innovative and globally competitive economic sector in the countries on the Mediterranean littoral. When successful, this should arrest the North-South divergent tendencies within the EU and therefore to dynamically stabilize the common currency area.

The special nature of these areas and its success can be enhanced by an adjusted tax regime (the third issue mentioned above). Again, the details are specific to individual countries. Here it should be only mentioned the need for the preservation of a hardly won public finance stability and the motivational role of capital gains in the establishment and success of business endeavors financed by the venture capital.

The EU with cooperation of national government sets the rules governing this new reality. However, the actual activities are by and large private sector financed and operated. This by itself should contribute not only to the renewed employment dynamics, but to the stabilization of public finances as well.

Currently, the European authorities are taking steps to deepen the European integration by expanding the common economic institutions. The major steps here are the Banking Union (in the process of implementation) and the Capital Markets Union (in the beginning). Furthermore the idea of a structural convergence was introduced, understood as a process of creating the similar (if not the same) legal and institutional environment in all areas of economic activity in all states sharing the common currency, provided that the autonomy of individual states and hence the existing principles underlying the European treaties are preserved. (Buti and Turrini, 2015).

The political commitment to furthering the processes of a structural convergence as a part of a deepening of European integration processes was announced in Juncker at el. (2015).

Any discussion of the issue is conditioned on the definition of the subject. What is the "structural convergence" or for that matter the "structural divergence"? In this analysis we accept the interpretation of the term "structural" as describing the set of preferences, political, economic, social and legal institutions and the associated policies and decision making processes. (I.e. we exclude the interpretation of "structural" as referring to the composition of economic activities and industries.)

In the context of the current analysis, structural convergence can be thought about in two ways. One, which could be called the "absolute" structural convergence is the transfer of institutional arrangements, policy formulations and decision-making procedures to the EU (or the Eurozone) levels. Participating member states experience the $100 \%$ loss of autonomy in such cases. The history of the European integration can be interpreted as this type of the structural convergence. It includes wide variety of actions, from the "European Treaties" (the Lisbon Treaty of 2009 is the last in the long line of those), binding decisions of the European summits (some may require ratifications by the participating countries) to the EU commission directives and judgements of the European Court of Justice.

Institutional, policy and decision making structures apply uniformly across the participating countries. It can be argued that this process of absolute structural convergence in Europe was rather successful in general terms, even if the lack of a real convergence might suggest otherwise. (It is far beyond the subject of this analysis to provide a detailed discussion of the history of European integration. Moreover, the real economic convergence often fails even 
in the unified national states - Italy is the best known example - where the structural convergence is absolute by definition.)

In the context of the EU and the Eurozone the latest examples of absolute structural convergence are the ongoing projects of the Banking Union and the Capital Markets Union. High hopes are associated with these projects as far as the real convergence is concerned - but results are still in the future.

Second type of a structural convergence addresses the situation when the institutional or policy arrangements in different countries are getting closer together (becoming the "more similar"). But the jurisdiction remains on the national level, with no (or a very limited) common EU action.

The discussions (and sometimes actions) in this area are related mostly to labor markets, business creations and operations environments, and legal structures and procedures. Taxation, health care and education are also involved. The basic idea is the identification and the subsequent emulation of the "best practice" - with the hope that this will contribute to the real convergence and the EU and the Eurozone's political and social stability.

However, several issues should be raised in this context. To start, one may ask about the determination of the "best practice". From the available literature, it appears to be a kind of arrangement which is instrumental in achieving the predetermined goal - be it the growth of the GDP per capita, productivity, competitiveness or the level of employment. But if it is so why not to adopt such an identified "best practice" as a kind of the EU standard something which would fall under the above discussed category of the "absolute" structural convergence. The lack of the needed political consensus may be the most likely reason - but then why should such steps be taken by individual countries independently?

Second, one may raise the question of the suitability of particular institutional or policy arrangements across the board - a precondition for the convergence. After all there are the reasons - historical, cultural, demographic, perhaps even differences in the climate - why EU and the Eurozone member countries differ and insist on the preservation of significant political and institutional autonomies. Absent this the unified European superstate would be created a long time ago.

And third, there is the question of costs - or more precisely the North - South transfers. It was pointed out that the most successful structural reforms in any European economy - the German Hartz IV package of labor markets and welfare reforms - was only made possible by Germany violating the original Stability and Growth pact in 2003 and 2004. One would assume that similar reforms introduced in the states of the South (the approach often advocated) would be costly and would require the EU's - i.e. the North - financial support. And in the current circumstances this is far from certain.

Hence: structural reforms - i.e. the structural convergence - are indeed useful and if designed thoughtfully they may be the key for overcoming the real divergence. However, the subject is far from simple and it would be naïve to expect the quick results.

The process of innovating and structurally modernizing the EU is extremely important and perhaps inevitable for the EU's survival. However, it is necessary to keep in mind that suggestions above are designed (and will) to produce the across the board gains in the medium and long runs, the short run need for the resource reallocation will likely result in individuals (and/or groups) which may find themselves on the losing side.

To address this issue several things should be remembered. First, the impact of the reform processes will differ by a country. Hence the response (help to the affected individuals or groups) will differ by the country. This will be only exacerbated by the still preserved cultural, social and economic differences between the EU countries.

Second, the costs of the adjustment cum help programs - as far as their necessity stems from the policies necessary to enhance and advance the EU community - should be, at least partially, financed from the common EU level. Common EU taxes on the activities as entertainment, advertising, wireless communications etc. appear very attractive in this context.

And third, given the inevitable national specificity of the desirable adjustment cum help programs, these should be designed together by affected nations (individually) and the EU - which indeed should carry a share of costs.

The potentially major issue not discussed in this analysis, the one which may affect the formation of the capital markets union in the EU and especially its desired role in fostering the activities of the venture capital, is the paucity of the non-governmental and the non-bank wealth institutions within the EU. IN USA those institutions (pension funds, university endowments, insurance companies and the large variety of the independent hedged and other investment and money funds) formed the backbone of the necessary fund suppliers to the venture capital industry. To 
develop the similar sources in the context of EU (and how to proceed in this cases) is indeed the major subject for the future research and analysis.

\section{Conclusion}

In conclusion, it has to be emphasized again that EMU is first and foremost the political arrangement, albeit with a significant economic impact. Its success is therefore determined by the political will to remain the member of the arrangement. This in turn will be influenced by the impact of relative economic performances on the domestic political processes in individual Eurozone member countries. But it must be stressed here that economic considerations, even if they receive the most attention from both the economists and the general public, are only a part of the overall process of political decision making, and may be not the most important ones. Countries engagement in complicated structures of the global security and political and economic relationships goes far beyond a simple calculus of economic gains and losses. Ans so is a detailed (country by country) discussion of the "structural convergence" and its development in an operational concept.

Indeed, in the first 23 years of existence, the EU was a reasonably cohesive economic and political arrangement. However, significant cracks in its façade are clearly developing in the areas most important for the long run economic performances of individual countries - investments and competitiveness. Unless addressed, these may constitute significant, and perhaps ultimate, threats to the Eurozone cohesion and perhaps to its existence.

\section{References}

Buti, M., \& Turrini, A. ((2015). Three waves of convergence. Can Eurozone Countries start growing together again? VOX CEPR's Policy Portal, April $17^{\text {th }}$.

Chen, R., Milesi-Ferretti, G-M., \& Tressel, T. (2012). External imbalances in the Euro Area. IMF Working Paper, $12 / 236$.

EMU@10. (2008). The First Ten Years: A Resounding Success. Quarterly Report on the Euro Area, 7(2).

Eurozone Portal. (2014). from http://www.eurozone.europa.eu/euro-area/topics/the-eus-response-to-the-crisis/

Hill, J. (2014). Capital Markets Union: Finance Serving the Economy. Speech at Finance and Growth Conference, Brusseles, $\quad$ Belgium, $\quad$ November $\quad 6^{\text {th }} . \quad$ Retrieved from http://ec.europa.eu/rapid/press-releaseSPEECH-14-1460.en.htm

Janning, J., \& Moller, A. (2016). Leading from the Center: Germany's New Role in Europe. European Council on Foreign Relations, July.

Juncker, J-C., Tusk, D., Dijsseelbloem, J., \& Draghi, M. (2015). Preparing for Next Steps on Better Economic Governance in the Euro Area. Informal European Council, Brusseless, Belgium, February $12^{\text {th }}$.

Juncker, J-C. (2014). A New Start for Europe: My Agenda for Jobs, Growth, Fairness and Democratic Change. Opening Statement at the European Parliament Plenary Session, July $15^{\text {th }}$. Retrieved from http://ec.europa.eu/about/juncker-commission/docs/pg.en.pdf

Leandro, A., \& Romero, M. (2016). Spanish Unemployment and the Effects of the 2012 Labour Market Reform. Bruegel, July 4.4 Retrieved from http://bruegel.org/2016/07/spanish-unemployment-and-the-effects-of-the-2012-labour-market-reform/

Ruscher, E. (2015). An Overview of Market Based Adjustment in the Euro Area in the Light of the Crisis. Quarterly Report on the Euro Area, 14(4).

Rusek, A. (2012). The Eurozone Imbalances: Real Convergence or Policy Divergence. In Ender Demir, Sami Akron, Nur Gunay, \& Danielle Toninelli (Eds.), EBES 2011 Anthology (pp. 3-9). Istanbul: Eurasia Business and Economics Society.

Terzi, A. (2016). An Italian Job: The Need for Collective Wage Bargaining Reform. Bruegel Policy Contribution, Issue 2016/11, July.

Thimann, C. (2015). The Microeconomic Dimensions of the Eurozone Crisis and Why European Politics Cannot Solve Them. Journal of Economic Perspectives, 29(3), 141-64.

TSCG. (2012). Retrieved from http://www.mfa.gov.lv/data/aaa/stabilitatesligums_en.pdf

Veron, N. (2014, November). Defining Europe's Capital Markets Union. Bruegel Policy Contribution, (12). 